\title{
Collective memory and research-led filmmaking: Spatial legacies of dictatorship in
}

\section{the Dominican Republic}

Lisa Blackmore, University of Essex

lisa.blackmore@essex.ac.uk

This article explores theoretical-methodological challenges in researching the formation of collective memory in the wake of dictatorship. The worldwide growth of memory sites suggests space crystallizes memory into stable formations (Assman, 1995). However, rather than monolithic discourses, environments attest to complex processes of memorialization and willful amnesia. I propose that research-led filmmaking can draw out spaces' heterogeneous "stories in waiting" (de Certeau, 1989). Through the documentary After Trujillo (2016), which revisits memory sites and ruins of Rafael Trujillo’s dictatorship from 1930-1961 in the Dominican Republic , I assess how working at the interface between research and film can: 1 . Probe space's testimonial capacity; 2. Engage audiences in public debates about violent pasts; and 3. Stimulate sustainable discussions through online platforms. Given that films still lack recognition as academic outputs, at stake here is the claim that creative methodologies constitute "a form of research" and "detectable research outputs" (Smith \& Dean 2009).

Keywords

collective memory; space; dictatorship; documentary filmmaking; modern ruins 


\section{Introduction}

In his theory of collective memory, Jan Assmann (1995) argues that texts, images, buildings, monuments, and landscapes all crystallize memory into stable formations that can be passed from one generation to the next (p. 132). According to this conception, organized commemorative activity sets in place common horizons, turning the past into a shared heritage that undergirds forms of societal consensus. While Assmann's theory has been influential insofar as it offers guidelines for the institutionalized memory politics he advocates, when researching the formation of collective memory in the wake of political repression and human rights abuses it is vital to consider the possibility that memory does not crystallize into stable, monolithic, or static forms. Rather, as they are shaped by remembering and forgetting, stories and silences, volumes and voids, “memory's records are full of gaps" (Kracauer, 1995, p. 50). In light of these irregularities, studies of the processes of remembrance of historic atrocities must also account for the unpredictable and heterogeneous ways that people engage with the past and its memorialization.

If mutability and heterogeneity are intrinsic to memory, then one way to explore them is through physical spaces linked to the past. The rise of memory sites that have emerged in the wake of human rights abuses from Cambodia to Rwanda, from Germany to Spain, and from Central to South America, is proof that space is entwined with processes of civic remembrance of traumatic experiences, whether they be genocide, war, torture, or political repression (Starzmann \& Roby, 2016). The struggle to form collective memory is clearly a global phenomenon, one that is based on the credence that spatial arrangements can effectively shape memory into enduring forms. This precept holds that memory sites stand as stable landmarks of past violence. Yet, for all 
their apparent solidity, such sites—like memory itself-are open to fissures, contested meanings, and even physical decay and ruination. Given that the preservation of memory and space alike require what Assmann terms a "kind of "cultivation"” (1995, p. 131), the decline of physical sites that index past atrocities can indicate ambivalence or lacunae in processes of remembrance. Such spatial irregularities can be accounted for, at least in part, by theories of space that approach it as a socially-produced phenomenon whose complexity and meanings always exceed abstract designs and architectural intention (Lefebvre, 1992). In the context of post-traumatic memory formation, this general theoretical principle can be taken further: recognizing the mutability of space and its resistance to monolithic narratives disturbs the foundations of memory sites. Instead of stable landmarks that tell consensual accounts of the past, sites of remembrance (and forgetting) stand as generative resources that enable us to unearth the complexities and inconsistencies of how public remembrance takes shape in space.

In this article, I propose that the methodology of research-led filmmaking can draw out "fragmentary and withdrawn histories ...[and] stories in waiting" from spatial legacies of dictatorship, thus shedding light on the irregular formation of collective memory and the diverse ways that people engage with the past through physical sites (de Certeau, 1988, p. 117). According to one broad-based definition, research-led films are "outputs, by-products, records of research undertaken, dissemination tools or practice-based research itself. They may include reconstructions and enactments, animations, installations and gallery pieces, games, interactive storytelling or co-produced work including collaborations with community groups, and may take the form of documentaries, visual essays or broadcast programs" (Arts and Humanities Research Council, 2016). In the pages to follow, I argue that incorporating audiovisual 
methodologies into academic work is an expedient way to research space and memory, which both supports fieldwork and analysis, and dissemination and engagement.

I take as my case study Después de Trujillo (in English After Trujillo; Blackmore \& Domínguez Dubuc, 2016), a 72-minute research-led documentary made in collaboration with the filmmaker Jorge Domínguez Dubuc, which focuses on the spatial legacies of Rafael Trujillo's dictatorship in the Dominican Republic (1930-1961). Trujillo's tyrannical, one-party state deprived ordinary Dominicans of their basic democratic freedoms and imposed diverse forms of social control of their daily lives (Derby, 2009). The regime enacted widespread political violence, persecuting and torturing Dominican dissidents (Turits, 2003) and murdering thousands of Haitians in the border massacre of 1937 (Paulino, 2016). As well as violence and repression, the Era of Trujillo was also a time of economic growth and modernization, in which the nation's landscape was significantly modified. Hence, Trujillo exploited urban design, monumental architecture and public spectacle to offset his nefarious image, creating a veneer of national progress that also served to entrench his dictatorship.

Although Dominican Law 5880 has prohibited public praise of Trujillo’s “tyrannical and antidemocratic" regime since 1962, the institutionalization of memory politics is a relatively recent development. Only in 2000 did a presidential decree declare the family home of the murdered Mirabal sisters (immortalized in Julia Álvarez's bestselling novel In the Time of the Butterflies) an extension of the National Pantheon. Similarly, it was not until 2010 that the Memorial Museum of Dominican Resistance was inaugurated in Santo Domingo (Museo Memorial de la Resistencia Dominicana, 2017). After Trujillo was conceived as a means to chart the uneven terrain of public memory by exploring 
spatial remnants of Trujillo's regime, manifested both in the formal memory sites created to honor its political opponents and the ruination of constructions leftover from dictatorship.

This case study offers a prism through which to scrutinize the interface of memory politics and the built environment in postdictatorial contexts, and to assess the affordances of research-led filmmaking as a methodology to explore human rights memory. Research-led filmmaking still lacks recognition as an academic output; hence, at stake in this discussion is the claim made by Smith \& Dean (2009) that creative methodologies have a dual status in academia: they are both practice-led "form of research" and a means of producing "detectable research outputs" (p. 5). Still, this inquiry is about more than the expansion of scholarly methodologies; it envisages opportunities to bridge the divides that often exist between scholarly work and public debates. With this in mind, in the pages to follow I chart the conceptualization, production, and dissemination of After Trujillo to ask for the capacity of research-led

film to: 1 . Respond to theoretical debates about space; 2 . Engage heterogeneous audiences in debates about space and memory; and, 3. Stimulate sustainable forms of dissemination and interchange through digital platforms.

\section{Memory sites and testimonial spaces}

In his influential theory of collective memory, French sociologist Maurice Halbwachs (1950) held that space serves as a testimonial "framework" for collective memory, counteracting the ways that "the memory of involvement in the events or of enduring their consequences, of participating in them or receiving a firsthand account from participants and witnesses, may become scattered..." during the passage of time 
([1950], 1980, p. 79). Against this transitoriness of memory, Halbwachs pitted the tangibility of space and its mnemonic capacity, stating that "we can understand how we recapture the past only by understanding how it is, in effect, preserved by our physical surroundings. It is to space -the space we occupy, traverse, have continual access to, or can at any time reconstruct in thought and imagination- that we must turn our attention" (1992, p. 173).

Space is fundamental to human rights memory. Memory museums, monuments, and other sites of conscience are founded on the conviction that physical sites can stimulate civic remembrance and symbolic reparations for traumatic events, serving as literal instances of what Pierre Nora (1989) termed lieux de mémoire: that is, places predicated on the "will to remember ... to stop time, to block the work of forgetting ... [that] owe everything to the specificity of their location" (p. 19-22). The growth of organizations like the International Coalition of Sites of Conscience (2016; ICSC for short), a global network of more than two hundred members, and the Latin American and Caribbean Memory Sites Regional Network, attest to the traction of the paradigm that holds that physical sites offer object lessons in historical events, which hold the potential for symbolic reparations and to shape future actions in line with a sense of common humanity. As ICSC puts it: "In post-conflict regions, Sites of Conscience are trusted organizations and spaces that address the needs of communities transitioning from conflict," which can "move people from memory to action" (2016). Such sites encompass a range of typologies, including trauma sites that stand as "material testimonies of violence and horror" (Violi, 2012, p.37), memorial museums that rewrite history in a critical light (Andermann, 2015), and newly commissioned monuments and memory parks that deploy aesthetic experience to foster empathy with victims of 
violence (Bell, 2015). In the Dominican Republic, they are similarly varied. Santo Domingo features numerous statues, murals, monuments, and museums, which honor anti-Trujillo activists and serve to host forms of organized commemoration. Rural memorial gardens beyond the capital literally "cultivate" a space for remembering the three Mirabal Sisters (murdered in 1960 by Trujillo’s regime) "always alive in their garden," as a commemorative stone located there pledges.

While the worldwide growth of memory sites signals consensus regarding the interrelation of space and memory, scholars and stakeholders often dispute the effectiveness of their designs and itineraries in generating critical reflection and awareness of past atrocities. This occurs not least because experiences of memory sites are inevitably contingent on the spectrum of visitors' viewpoints; appraisals might range from profound emotional engagement to relative indifference, depending on the person's experience. Consider the different conclusions that scholars have reached with regards to Villa Grimaldi, a community-led memorial garden created on a site of torture used by Augusto Pinochet's dictatorship in Chile (1973-1989). For some, the transformation of a trauma site into a carefully tended garden flattens the shock effect of past atrocities (Richard, 2001). For others, the garden's motif of generation might allow visitors to reconnect to that past and think beyond trauma (Andermann, 2012). The agency that diverse stakeholders (including policymakers, caretakers and visitors) have in shaping memory sites opens them up to polyvocal interpretations that are inflected with different political agendas, personal histories, and specific experiences of place. In this sense, spaces are not, so to speak, set in stone, but are produced through users' experiences, as Lefebvre argued (1992). Moreover, the spatial matter to which Halbwachs attributed a mnemonic function is not always characterized by stability and 
permanence, but by mutability and ambiguity. The preservation of built and natural environments requires constant maintenance, meaning that the vitality of memory sites depends on multiple factors, which go from judicial protection and institutional oversight, through to the facilitation of visitor access and the daily labor of caretakers.

Still, formally constituted memory sites are not the only spatial typologies that are germane to the interface of space and memory. The spatial turn in cultural criticism generated new approaches that invite an acknowlegement that other types of space, which we might call "testimonial spaces," can also attest to traumatic pasts even if they are not designed to be memorials. Huyssen (2003) has shown how different types of urban space exist as "palimpsests" in which traces of the past endure in the present. Similarly, WJT Mitchell has argued cogently that since social and political phenomena inhere in spatial formations tout court, even sites that seem innocuous or picturesque can harbor a "dark side" that speaks of violence (2002, p. 6). As I argue elsewhere, the monumental modern architecture built under repressive regimes was often leveraged to "screen" political violence from public view by directing attention to public spectacles staged to glorify leaders and assert national progress (Blackmore, 2017). As sites explicitly devised to entrench dictatorship, they are "conceived spaces" that speak the language of power (Lefebvre, 1992).

Admittedly, the testimonial capacity of the grandiose constructions used to lionize repressive regimes is not as evident as that of the memorials emplaced to found itineraries of civic mourning and remembrance. However, in postdictatorial settings, such sites are much more than aesthetic heritage; they too are palimpsests that bear the traces of violent pasts and authoritarianism. In the Dominican Republic, Trujillo's rule 
benefitted directly from the development of the Modern Movement in architecture, which reached its apogee with the construction of the Fair of Peace and Confraternity of the Free World, a fairground complex of pavilions and permanent buildings raised in 1955 in Ciudad Trujillo (as Santo Domingo was then called) to host lavish festivities commemorating 25-years of Trujillo's rule (Rancier, 2005). Inspired by New York's 1939 World's Fair, the 1955 exposition exemplifies the way that urban design buttressed the repressive regime. The Theater of Water and Light, for instance, whose dancing fountains provided the backdrop for the coronation of Trujillo's daughter as queen of the Fair of Peace, epitomizes the propagandistic function of sites of spectacle created to enhance the regime's public image and to distract from the violent means it used to retain power.

The fates of such sites become imbricated with memory politics and civic remembrance in postdictatorship contexts. Not only does the impact of time and usage mean that these “conceived spaces" become dynamic "lived spaces", whose meanings exceed and contest architects' and planners' original designs (Lefebvre, 1992). Cast amid the shadows of past violence, sites built by bygone regimes epitomize the irregular ways that public memory, quite literally, takes place. That is to say, the preservation or ruination of spatial legacies of dictatorship reflects the ways that commemorative practices cohere (or not) into societal consensuses. If buildings linked to repressive regimes are left to ruin, their fragmented forms can signal fissures in the crystallization of public memory. Retracing processes of ruination is therefore a productive way to ask why some places are remembered and others are willfully forgotten since, as Gastón Gordillo (2014) recently argued, when people decide to care for ruins and rubble left out of official memory politics or judicial protection, their actions give voice to alternate 
memories and interpretations of spatial meanings that might be missing in institutionalized narratives of the past. Similarly, other recent scholarship has shown (Lazarra \& Unruh, 2013; Olalquiaga \& Blackmore, 2017) that modern ruins are "telling" sites whose complex stories can be unearthed to call received narratives into question. In this sense, and perhaps most importantly, research methodologies that engage ruins as testimonial spaces can broaden discussions about collective memory, broaching questions that not only pertain to specialized and institutionalized fields, but that also have a bearing on grassroots memory and personal narratives.

\section{Showing stories of space and memory After Trujillo}

The section above contended that space has testimonial capacity; that sites excluded from official memory politics also shed light on the formation of collective memory; and that users" experiences of spaces generate diverse "stories in waiting" that need to be drawn out. These principles informed Después de Trujillo (in English After Trujillo; Blackmore \& Domínguez Dubuc, 2016), a 72-minute long, research-led documentary on space and memory in the Dominican Republic, produced as part of my postdoctoral research on the project Modernity and the Landscape in Latin America: Politics, Aesthetics, Ecology, directed by Jens Andermann at the University of Zurich from 2014 to 2017. The research and film aimed to bring dictatorship, modern architecture and memorial sites on a critical common ground to ask: How do built environments entrench power through modern architecture and public spectacles? How do memory sites commemorate the political resistance that occurs "off stage" and out of public view? And, how do abandoned or ruined sites left over from dictatorial regimes attest to unresolved relations to traumatic pasts? 
On the surface, the crimes and human rights abuses committed during Trujillo's dictatorship (1930-1961) appear to have crystallized in collective memory. As well as being “back in fashion” among historians (Moya Pons, 2008, p. 518), Trujillo’s sexual misdemeanors and violent rule have been the topic of the bestselling novels and subsequent film adaptations of Mario Vargas Llosa's La fiesta del chivo (2000) and Julia Álvarez's In the Time of the Butterflies (1994). More recently, the Trujillo era informed Dominican-American author Junot Díaz's Pulitzer Prize-winning novel The Brief Wondrous Life of Oscar Wao (2007). In global human rights and feminist groups, the brutal murder of the Mirabal Sisters because of their collaboration in the 14 June Movement against Trujillo is a well-known atrocity, marked annually on November 25 by the United Nations' International Day for the Elimination of Violence against Women (Robinson, 2006). In the Dominican Republic itself, although critical remembrances of the dictatorship were stunted through the post-Trujillo decades when his former right-hand man Joaquín Balaguer was in power (1966-1978; 1986-1998), memory politics consolidated somewhat with the new millennium. New public monuments, state legislation consecrating victims of the regime as national heroes, and rich cultural production from documentaries through to plays, have all played a part in configuring a more durable repertoire of commemorative practices (Blackmore, 2015).

Against this apparent abundance of organized commemoration, the aim of After Trujillo was to probe the formation of collective memory in built environments and natural landscapes, using the spatial legacy of the dictatorship to explore the ways in which Dominicans have chosen to remember and forget Trujillo. In this sense, the film aimed to establish a dialogue between conventional memorial gardens and monuments, and ruins of dictatorship whose contested fates and meanings demonstrate irregular 
engagements with the dictatorial past. Expanding the notion of memory sites to proTrujillo constructions thus aimed to interrogate sites beyond the pale of conventional memory politics. The physical condition of pro-Trujillo architecture, and debates about whether it should be razed, preserved or re-invented, are directly related to the judicial and political force fields that both inform memory politics and plague it with paradoxes. For instance, policymakers tasked with preserving the country's architectural heritage must also ensure that they uphold the 1962 legislation that outlaws public exaltation of Trujillo's tyranny. In practice, however, this law itself is apt to generate ambiguities. While it stipulates that the public domain should include no "emblems" that glorify Trujillo, physical sites such as the Fair of Peace and the Castillo del Cerro (a former mansion owned by the dictator, in his native city of San Cristóbal) decorative motifs (such as the five stars designed to exalt Trujillo's military rank as Generalísimo) live on as part of the original architectural designs. The fact that such motifs still emblazon public monuments and buildings evinces grey areas in the interfaces of post-dictatorship legislation, architectural heritage policies, and memory politics.

Digital cinema and drone footage for the film was made during a month-long fieldwork trip to gather archival materials, meet local academics and stakeholders, and conduct site visits to conventional memorials and other constructions from the Trujillo era, including the dictator's former mansions. The initial pre-production phase established research questions that would guide the film and fieldwork, alike, without imposing the strictures of any pre-existing script, storyboard or conclusion. As a result, the film's making (and the research itself) took an exploratory course as the process of filming and interviewing people unearthed new leads to additional archives, historical witnesses, and places, which were subsequently incorporated into both the audiovisual and textual 
outputs. Working at the interface of research and film meant that audiovisual and scholarly methodologies remained in constant dialogue, yet while the film was initially research-led the post-production process offered structures and methods which meant that the film could pose questions rather than impose an intransigent authorial thesis. Essays in humanities scholarship customarily follow a paradigm that privileges textbased communication, clear argumentation, and an identifiable conclusion, yet in documentary filmmaking the images do work of their own. Film allows for a dialogic and plural mode of "showing" stories, rather than "tellling" them, to echo the terms that media theorist Linda Hutcheon uses to describe the shift from print to performance (2006, p. 38). Similarly, non-verbal interludes (such as those featuring frames or sequences accompanied only by ambient sound, or the visual transitions from one frame to another) provide the viewer with greater interpretative freedom, allowing room for ambiguities that are less prevalent in academic articles, whose argumentative thrust tend to move inexorably from thesis to conclusion.

A further consequence of this process of "showing" stories of space and memory was that editing involved staying with the image over protracted periods of time. This lengthy contact with the material gathered during fieldwork in turn created a deferral of the process of reaching definitive conclusion about its meaning. Although the basis for the project was to produce a research-led film, this apparent hierarchy was dissolved in practice. Insofar as post-production demands sustained attunement and attendance to non-verbal and visual content in which images do work of building meaning(s), the editing process has the potential to feed the "showing" mode back into the habitually "telling" mode of academic writing, perhaps making room for more imaginative speculation amid the tenacious argumentation that tends to characterize text-based 
scholarship. Put briefly, this feedback loop between the methodologies of research-led film and film-led research maps onto the broader field of scholarlship that has noted overlaps in research-led practice and practice-led research in the creative arts (Smith \& Dean, 2016).

\section{Synopsis}

After Trujillo tells the story of Trujillo's violent dictatorship through the marks it left on the landscape, combining historical documents, such as photographs, architectural plans, and propaganda publications, with new footage of testimonial spaces, ranging from archives, monuments and memory gardens, through to city streets and urban ruins. Broadly speaking, the film's structure is chronological and can be summarized through four core themes: the relations between space and power; forms of repression and resistance; analyses of memory politics and memorial sites; and speculative opinions about the architectural legacy of the dictatorship, its abandonment or reinvention. Rather than attempt an exhaustive catalog, the film draws out contested spatial interpretations of specific sites through interviews, archival documents and new footage.

The film begins with a brief introduction to how Spanish colonialists and the first U.S. American occupation (1916-1924) centralized power to divide and rule the territory. Then, it charts Trujillo's rise to power in 1930 and the way the San Zenón Hurricane created a clean slate on which the capital city of Santo Domingo could be rebuilt in Trujillo's “image and likeness" and renamed as Ciudad Trujillo, as architect and architectural historian Omar Rancier puts it. As architects and historians identify the main strategies implemented under the regime to manifest the dictator's power in urban 
space, this first section focuses particularly on the design and propagandistic raison d'etre of the Fair of Peace and Brotherhood of the Free World, and on witness testimonies of the parades and events that, as one interviewee puts it, it was "dangerous" not to attend. In the second section, Tomasina Cabral (Fig. 1), an antiTrujillo activist imprisoned and tortured by the regime, provides a first-hand testimony of the genesis of the anti-Trujillo resistance movements and the uprisings that eventually led to the dictator's assassination in 1961. Details of the repression imposed on Dominicans through forced labor on road construction sites; the torture of political prisoners; and the assassinations of resistance opponents by the Military Intelligence Service (SIM) is conveyed by Roberto Cassá, an historian and director of the Dominican National Archive. The contributions from Luisa De Peña, the founding director of the Memorial Museum of Dominican Resistance, and the inclusion of torture photographs from the museum's collection, provide information and tangible evidence of human rights abuses under Trujillo.

[Figs. 1-3 near here]

Figure 1. Tomasina Cabral. Film still from After Trujillo (2016).

Figure 2. Ruins of Patria Mirabal's house, at the Patria Mirabal Memorial Garden, San José de Conuco. Film still from After Trujillo (2016).

Figure 3. Ruins of the Theater of Water and Light. Film still from After Trujillo (2016). The third section turns specifically to the period after Trujillo and what the geographer Rafael Emilio Yunén describes as the process of "de-trujillization" and the formation of collective memory through cultural production. Among the interviewees, stakeholders and historical witnesses lead the section that presents memory sites devised to 
commemorate the resistance movement. De Peña traces the evolution of memory politics and human rights awareness in the postdictatorship, clarifying the concerns and the work of victims' foundations as the motive for the creation of the Memorial Museum. She explains formal commemorative practices that occur in public monuments like the mausoleum for the soldiers killed during the abortive anti-Trujillo expeditions of Constanza, Maimón and Estero Hondo in 1959. Particular attention is also paid to the Mirabal Sisters House-Museum, the last home occupied by Patria, Minerva, and María Teresa Mirabal before their murder, and the Patria Mirabal Memorial Garden (Fig. 2). These rural sites, located hours from the capital city, strike a strong spatial contrast to the official, modern architecture built to glorify Trujillo, and the conventional monuments in Santo Domingo. Patria Mirabal's daughter, Noris González Mirabal, also offers a personal account in this section, where she clarifies the importance of specific plants and trees in the memorial gardens which she presents as "symbols" of freedoms, and explains the intersection of private space and public memory that occurred in the transformation of the Mirabal family home into the nation's most visited museum.

The fourth and final section of the film delves further into present day opinions about the fate of the different spaces and buildings leftover from the Trujillo regime. The contrasting opinions of caretakers, users, academics, and historical witnesses, converge to address the implicit questions raised by the film: Can modern architectural heritage be dissociated from its genesis during dictatorship? Should the dictator's former homes be destroyed, demolished or repurposed? These questions are addressed through a number of specific sites. These include the Fair of Peace urban complex and two modern ruins there: Catalan architect Carles Buïgas' Theater of Water and Light (Fig. 
3) and the Venezuelan Pavilion, a daring modernist building designed by Venezuelan architect Alejandro Pietri for the regime of Trujillo ally General Marcos Pérez Jiménez. The other sites foregrounded in this final section are two of Trujillo's ex-residences in San Cristóbal, whose respective abandonment and reinvention depict the inconsistency of institutionalized memory politics regarding sites linked to the dictator. The Casa de Caoba (Mahogany House) went from being a popular Trujillo Museum in the aftermath of dictatorship to an abandoned ruin safeguarded only by the members of the local community invested in its conservation. By contrast, the Castillo del Cerro (Castle on the Hill) initially fell into ruin, but was restored and re-inaugurated in 2006 as a public museum and National Penitentiary School for prison guard training. In this section, the architect Omar Rancier speculates that this change of function marks a "poetic" shift of historical fortunes that mean that today "justice is located in the dictator's house."

As the film comes to a close, the interviewees ponder whether or not such sites can effectively overcome their associations with dictatorship or whether leaving them to ruination and abandon could constitute a form of public vengeance through willful amnesia. Amid the contrasting opinions that speculate on these testimonial spaces, only one consensus emerges: silence is not an option in human rights memory since, as Iván Fernández, one of the caretakers of Trujillo's ruined home so eloquently puts it: “la historia, hay que contarla"- that is, "the story/history must be told."

\section{Contested spaces, public debates}

Rather than utilize the authoritative voice of an omniscient or on-screen narrator to tell that story, After Trujillo is narrated entirely by Dominicans through edited footage in which the interviewees' contrasting perspectives are brought into dialogue with sites 
that show the irregular ways that memory has taken shape in space. Onscreen texts are used sparingly only to provide necessary information, such as at the outset when a brief text provides historical context and identifies the film's key themes of state violence, spatial arrangements, and collective memory, or throughout to identify sites and speakers, and to describe key historical events. In line with the theoretical premise that spatial experience is necessarily heterogeneous, the interviewees were selected for their diversity of disciplines, generations, and socioeconomic backgrounds. They represent: 1. Academics from history, geography, architecture, and art history; 2. Historical witnesses involved in the anti-Trujillo resistance, and victims of imprisonment and torture, or people whose family members were assassinated by the regime; 3 . Institutional stakeholders, such as the directors of the National Archives and the Memorial Museum of Dominican Resistance; 4. Caretakers and users of historical sites linked to the dictatorship.

These different voices also shaped the filmic register by generating a spectrum of perspectives, which ranged from theoretical and historical analyses, through to emotive, personal stories. After Trujillo was edited so that these different perspectives were placed intentionally in dialogue to raise more questions than answers. This transpires in sections on the Fair of Peace, which was renamed in the 1980s as the Center of the Heroes to honor the anti-Trujillo resistance. While the architect Gustavo Luis Moré contends it "has managed to overcome its pro-Trujillo regime ... thanks to time and use,” Emil Rodríguez Garabot, an urban planner and co-curator of the Dominican exhibition on the Fair of Peace at the Venice Architecture Biennial in 2014, disagrees, asserting that "it isn't a place where you remember anything except the celebrations of the Fair of Peace.” In the off-screen comments accompanying images of the Theater of 
Water and Light, taxi driver Leovirgilio Hernández offers another point of view, divulging urban abandonment in the Fair of Peace and explaining the tensions that have ensued from the former theater's use for sex work. "If someone comes from the newspaper and does a report on the place then the police are immediately on their [the sex workers'] backs," he states off-camera, before relaying the angry shouts that come from inside the building, which complain: "WWhat the hell are you recording? You're such a nuisance! Always bugging us! We can't even work in peace!"

Similar contentions emerge in the interviewees' opinions of the Casa de Caoba, Trujillo's one-time mahogany mansion that is now a rural ruin. Located up on a hill, locked behind gates, and accessed only by a stony path, today it is a blind spot and contested site of Dominican memory politics. The mansion's shifting fortunes saw it function as a museum that preserved Trujillo's belongings, before it was devastated by Hurricane David in 1979, then partially rebuilt and eventually abandoned anew. For architect Omar Rancier, it is symptomatic of the broader problem of deficient institutional oversight and "dubious criteria" of heritage policies that mandated its reconstruction using materials that altered the house's original wooden structure. No longer a home, nor a museum, nor an entirely empty ruin, the house languishes in institutional limbo. For Tomasina Cabral, it is akin to a site of trauma, because, as she exclaims, "Trujillo deflowered virgins in that house!" Yet, the caretakers, Carlos Figueroa and Iván Fernández, see the house as part of the local community's collective memory, a place that could remedy rural poverty if the government would only realize that as "a historic house" it could be a "tourist attraction." 
The public screenings organized to disseminate After Trujillo in the Dominican Republic in late 2016, just after it was completed, were intended to foster additional debate around the film's implicit questions. By maintaining contact with the interviewees and keeping them abreast of its progress, we were able to organize eight screenings in a variety of settings to which the different interviewees were somehow linked. These included private and public universities, the Memorial Museum, and the National Archive in Santo Domingo, and a private cultural center in Santiago. Coverage in the local press, radio, and an interview on the state television channel, subsequently led to further dissemination activities, including a broadcast of the film and a prerecorded discussion about it on the state television channel, and screenings and discussions with students of art and communications at a private higher education institute. At almost all of the events, panel discussions with interviewees and local academics then opened up to public debates, which were filmed to be shared online.

In the editing process, we emphasized certain key phrases and provocative opinions that would stimulate reflection and debate in viewers. The idea, expressed by Rancier, that "one of the options that the people have is to forget the things associated with the dictatorship," is one such example, which generated contrasting opinions when members of the public applied it to the Casa de Caoba. At the Santiago screening, one young university professor expressed a desire to tear down with a sledgehammer and rid the landscape of the decaying mansion. At other screenings, a memory policymaker and an art student both advocated total reinvention of the house, suggesting that it should be turned into the antithesis of what it was under Trujillo: a refuge for young female victims of sexual abuse. For others still, neither of these ideas was a feasible way to confront the past. 
A further aim of the screenings and public discussions was to pose the spatial legacy of dictatorship as a form of national, albeit disputed, heritage. Just as After Trujillo placed memory sites and other testimonial spaces on common ground, the screenings sought to cultivate dialogue between architects involved in heritage policies, and policymakers and victims engaged in memory politics, with the hope that these conversations might cut across conventional borders, generations and disciplines. One salient example of the intersection fostered between different groups and disciplines occurred during the discussion at the Memorial Museum in December 2016, where the museum director, Luisa De Peña, the historical witness Tomasina Cabral, and the daughter of Patria Mirabal, Noris González Mirabal, participated as panelists. Strikingly, the predominant topic of the discussion between the panelists and the public was not the memory sites and gardens they are all involved in preserving and cultivating. Rather, it was the ruins of dictatorship whose preservation is usually a topic dominated by architectural historians, but whose institutional limbo captured the attention of the audience at the Memorial Museum and stimulated speakers to put forward different proposals for the future restoration or demolition of these ruins.

\section{Funding and sustainability}

Compared to conventional print and online publications, research-led films have much less recognition as academic outputs; hence funding bodies do not necessarily cover costs incurred in their production. To confront this situation, we developed resourceful strategies to minimize costs, such as working with a skeleton team, using minimal technology, and sharing the tasks of production and directing. The decision to make After Trujillo a non-profit, open access film, with a Creative Commons license, 
facilitated relations with partner institutions that provided archival photographs and documents free of charge. A grant awarded by a private cultural foundation covered the cost of sound editing, while the production of DVDs (to donate to partner institutions in acknowledgement of their generosity in the provision of archival materials) was funded by the host university.

The donation of DVDs means that the film should appear in library catalogs and institutional collections, but dissemination and engagement were principally oriented toward providing access to the film and its associated research via an online platform. This decision benefited from the growth in what Klein and Gold (2016) call the "big tent" of digital humanities in the past decade, wherein digital technologies and online platforms are put to academic ends, to disseminate research to other scholars and students, and to create online engagement between academic and public spheres. This shift in academic culture created the possibility of obtaining a grant to fund the construction of the e-learning blog Después de Trujillo (Blackmore, Domínguez \& Muñoz, 2016). As well as mitigating the deficit in funding to cover the final stages of editing, this grant funded the participation of an undergraduate student who created the project's tailor-made website, hosted by the university server. Given that technical training is not always part of academic education, the digital learning department provided vital know-how; skill transfer and training for the project assistant; and a reliable, institutional channel on which to host the film, without distractions from information found on commercial platforms.

The site provides a platform to view the film, as well as information about the research project, biographies of the sites and speakers, a list of screenings, study materials, and a 
contact form. Self-publishing software also enables it to function as a blog to publish research articles, guest posts, and reflections on the filmmaking process. Although publishing a film online does not guarantee that people find and view it, as Stephen Robertson (2016) shows with regards to the outreach capacity of digital history platforms, it is possible to mitigate the danger that online platforms disappear among the plethora of information on the web by establishing clear aims and a target public at the outset. As well as identifying the audience, other practical strategies have helped to support outreach and the film's online presence. Promoting the film and the e-learning blog Después de Trujillo through a social media page, organizing public events, and securing press coverage, have all enhanced the site's search engine visibility, increasing visits to it and motivating researchers, academic institutions and members of the public to contact us about the project. The incorporation of the film onto academic syllabi at universities has created further opportunities for dissemination.

Finally, the completion of English subtitles has made it possible to organize screenings and public talks at universities in Europe, Canada, and the United States, thus broadening the diversity of audiences and generating interdisciplinary discussions with faculty and undergraduate and graduate students of history, criminal justice, and art history, among other fields. One specific result of this methodology has been the collaboration with a professor of architecture at the Universidad Nacional Pedro Ureña Henríquez, who used After Trujillo as a teaching resource and coursework exercise on an undergraduate course on the History of Dominican Architecture. After screening the film, students discussed the issues it raised and debated a series of questions that we provided in advance. Then, they used the ruined sites presented in the film as case 
studies to present strategies for the buildings' rehabilitation or alternate uses, a selection of which was subsequently published on our website.

The film was conceived as a forum to draw attention to the nexus of space and memory, present heterogeneous opinions about the legacy of dictatorship, and to build bridges with diverse audiences. At this point it remains early to assess the effectiveness of the project in creating a sustainable dialogue as lively as those that took place during screenings, but to date it is possible to envisage further dissemination and ongoing exchanges, such as the incorporation of the film as part of the guided tour for high school student groups visiting the Memorial Museum of Dominican Resistance and the National Archive's pledge to distribute copies of the film to public schools and colleges through the Dominican Republic.

\section{Conclusion}

The divergent opinions about memorial sites and ruins of dictatorship that emerged in the making and dissemination of After Trujillo lend weight to the thesis that memory and space are mutable and irregular phenomena, which are apt to erode if they are not preserved. Collective memory implies painstaking maintenance, demanding both unstinting institutional oversight and constant caretaking work to cultivate a common ground where past trauma can live on. Memorial gardens, such as those honoring the Mirabal sisters, provide object lessons in the way that space and memory are embedded in time. Similarly, Trujillo's crumbling mahogany mansion stands as a fragile reminder of what happens in the blind spots of civic remembrance. Caught adrift in the passage of time, even the most solid monument can disintegrate as the past recedes from view. The divergent voices that contested the fates of the dictator's former home, advocating either 
its demolition as a form of willful amnesia or its reconstruction as a route to symbolic reparation, make it clear that After Trujillo was able to draw out from this testimonial site "stories in waiting" that attest to Dominicans' heterogeneous relations to dictatorial past.

The second aim of this article was to advocate research-led filmmaking as creative methodology to study the formation of collective memory and a research output in itself. The public debates that took place in the public screenings of After Trujillo and partner institutions' plans for its ongoing dissemination all suggest that research films are a productive way of thinking through space and memory at a particular juncture. This implies, in turn, that insofar as a film is a temporal archive that captures a particular moment it is also exposed to the same shifts that the passage of time enacts on space and memory. In effect, by the time of film's premiere in Santo Domingo, less than two years after the footage was made, two of the sites featured in After Trujillo had undergone striking alterations. Amid a change of local government that had ushered in a new vision for urban renewal, sex workers had been removed from the Theater of Water and Light and the complex fenced off. Amid growing public discussions about the decline of the Venezuelan Pavilion and an art exhibition there that drew attention to its decline in 2016, the pavilion's custodians, the Society of Dominican Architects, had taken steps to rehabilitate the building by giving it a new coat of paint (Leonardo, 2017).

These spatial variations are the vital signs that processes of public remembrance and forgetting are constantly fluctuating, even as they are caught on camera. When contested sites associated with traumatic pasts become forums for public debate, they 
can come back into view-perhaps to become frameworks for collective memory, perhaps to be reinvented as a means to erase the past. Research-led filmmaking offers a methodology to capture "stories in waiting", yet its potential also depends on the recognition that, just as memory and space change, so too do new accounts emerge that demand updated appraisals. Far from exhausting perspectives on space and memory, then, using film to study these phenomena is a way to push beyond monolithic discourses and complacent arguments, opening academic research up to oftenunpredictable realities to which it must also constantly adapt.

\section{Acknowledgements}

After Trujillo pays tribute to the bravery of those who fought against dictatorship and to the will to memory of the Dominicans unwilling to let the legacy of violence crumble into oblivion. I would like to express gratitude to those who made the film's production possible, to the two anonymous reviewers for their encouraging and constructive comments, and to Professor Raulina Capellán and her students for engaging with the film and providing fascinating new interpretations of the ruins of dictatorship.

\section{Works Cited}

Álvarez, J. (1994). In the time of the butterflies. New York: Algonquin.

Andermann, J. (2015). Between the archive and the monument: Memory museums in postdictatorship Argentina and Chile. The International Handbook of Museum Studies: Museum Transformations 1, 181-206. 
Andermann, J. (2012). Expanded fields: Postdictatorship and the landscape. Journal of Latin American Cultural Studies 21(2). doi.org/10.1080/13569325.2012.694810

Arts and Humanities Research Council. (2016). The AHRC research in film awards 2016. Retreived from: http://www.ahrc.ac.uk/funding/opportunities/archivedopportunities/rifa-2016/

Assmann, J. (1995). Collective memory and cultural identity. New German Critique 65, $125-133$.

Bell, V. (2014). The art of post-dictatorship: Ethics and aesthetics in transitional Argentina. London: Routledge.

Blackmore, L. (2015). Violencia en el jardín de (la) Patria: la monumentalización de las hermanas Mirabal y el sitio de trauma en la posdictadura dominicana. Mitologías hoy 12. .doi.org/10.5565/rev/mitologias. 277

Blackmore, L. \& J. Domínguez Dubuc. (2016). Después de Trujillo/After Trujillo. 72 min. Online documentary. http://www.phil.uzh.ch/elearning/blog/despues-de$\underline{\text { trujillo/film/despues-de-trujillo/ }}$

Blackmore, L., J. Domínguez Dubuc \& M. Muñoz. (2016) Después de Trujillo. ELearning Blog. http://www.phil.uzh.ch/elearning/blog/despues-de-trujillo 
Blackmore, L. (2017). Spectacular modernity: Dictatorship, space, and visuality in Venezuela, 1948-1958. Pittsburgh: University of Pittsburgh Press.

Consejo del Estado (1962). Ley 5880 que establece penas contra las alabanzasal pasado régimen tiránico y Antidemocrático de Trujillo. Retreived from: https://bonoc.files.wordpress.com/2008/06/ley5880.pdf

De Certeau, M. (1988). The writing of history. Trans. Tom Conley. New York: Columbia University Press.

Derby, L. (2009). The dictator's seduction: Politics and the popular imagination in the era of Trujillo. Durham and London: Duke University Press.

Díaz, J. (2007). The brief wondrous life of Oscar Wao. New York: Riverhead Books.

Halbwachs, M. (1992). On collective memory. Trans. Lewis A. Coser. Chicago: University of Chicago Press.

Halbwachs, M. (1980). The collective memory. New York: Harper \& Row.

Hutcheon, L. (2006). A theory of adaptation. London: Routledge.

Huyssen, A. (2003). Present pasts: Urban palimpsests and the politics of memory. Stanford: Stanford University Press. 
International Coalition of Sites of Conscience. (2016). Truth and Justice. Retreived from: http://www.sitesofconscience.org/truth-and-justice/

Klein, L. \& M. Gold. (2016). Debates in the digital humanities. Minnesota: Minnesota University Press.

Kracauer, S. (1995). The mass ornament. Trans. Thomas Levin. Harvard: Harvard University Press.

Lazarra, M. \& V. Unruh. (2009). Telling ruins in Latin America. New York: Palgrave Macmillan.

Lefebvre, H. (1992). The production of space. Trans. Donald Nicholson. Oxford: Wiley.

Leonardo, E. (2017). The Venezuelan pavilion in Santo Domingo. In C. Olalquiaga \& L. Blackmore (Eds), Downward spiral: El Helicoide's descent from mall to prison (pp. 248-253). New York: Urban Research.

Mitchell, WJT. (2002). Imperial Landscape. In WJT. Mitchell (Ed.), Landscape and Power (pp. 5-34). Chicago: University of Chicago Press.

Moya Pons, F. (2008). La otra historia dominicana. Santo Domingo: Librería La Trinitaria. 
Museo Memorial de la Resistencia Dominicana (2017). Sitios de memoria. Retreived from: http://www.museodelaresistencia.com

Nora, P. (1989). Between Memory and History: Les Lieux de Mémoire.

Representations, 26, 7-24.

Olalquiaga \& Blackmore. (2017). Downward spiral: El Helicoide's descent from mall to prison. New York: Urban Research.

Paulino, E. (2013). Dividing Hispaniola: The Dominican Republic's border campaign against Haiti, 1930-1961. Pittsburgh: University of Pittsburgh Press.

Rancier, O. (2005). Santo Domingo, modernity and dictatorship. Docomomo, 13, 5356.

Richard, N. (2001). Sitios de la memoria: Vaciamiento del recuerdo. Revista de crítica cultural, 23, 231-271.

Robertson, S. (2016). The differences between digital humanities and digital history. In M. Gold (Ed.), Debates in the Digital Humanities. Minnesota: University of Minnesota Press. Retreived from: http://dhdebates.gc.cuny.edu/debates/text/76

Robinson, N. (2006). Origins of the international day for the elimination of violence against women: The Caribbean contribution. Caribbean Studies, 34(2), 141-161. 
Smith, H. \& R.T. Dean. (2009). Practice-led research and research-led practice in the creative arts. Edinburgh: University of Edingburgh Press.

Starzmann, M.T. \& J.R. Roby. (2016). Excavating Memory: Sites of Remembering and Forgetting. Miami: University of Florida Press.

Turits, R.L. (2003). Foundations of Despotism: Peasants, the Trujillo Regime and Modernity in Dominican History. Stanford: Stanford University Press.

Vargas Llosa, M. (2000). La Fiesta del Chivo. Madrid: Alfaguara.

Violi P. (2012), Trauma site museums and politics of memory. Tuol Sleng, Villa Grimaldi and the Bologna Ustica Museum. Theory, Culture \& Society, 29(1), 36-75. 